\title{
$\mathbf{F}: 2 \sqrt{\top}$
}

\section{CONTRIBUTION OF ENGLISH SPEAKERS TO SOUTH AFRICAN HISTORY}

When I was invited to make a contribution to this column, I asked the Editor to give me some sort of guide line on what he saw as being the nature of the column. The reply he gave was: It is intended to be a forum where one can grind one's favourite axe about the South African Defence Force; one does not have to tread on anyone's toes; in order to allow a similar measure of academic freedom as enjoyed by such prestigious periodicals as the United States Naval Institute Proceedings, contributions do not have to be vetted by one's boss. Looking at these guide lines I can't help thinking that whichever course of action I choose ... This leaves me with the difficult task of choosing an appropriate axe that needs grinding. The one that comes to my mind almost immediately is the lack of articles in Militaria on the history of the English speaking folk in South Africa. Before I go any further let me point out to the negativists (to whom any comment will always appear as adverse or destructive criticism) that one can be FOR something without being AGAINST something else.

At various times in my life I have come across so-called officially recognized facts in South African history from the Afrikaner's point of view that, if entirely correct, would preclude any role in that respect by the English folk. Take one very famous historical statement: ' $\ldots$ and thus the might of the Zulus was forever broken ...' (about the Battle of Blood River). If this statement were entirely correct, where did the mightiest army in Zulu history come from in 1876? To get the correct perspective on the quoted statement one should replace 'might of the Zulus' by 'Dingaan's might' and omit 'forever'. A representation of this critical period of our history is called for on the intimate and personal basis that only Militaria's writers seem capable of. Few people realize how delicately a large part of our country's future rested in the balance in 1876 and why. Most people nowadays seem to think that a smallish Transvaal commando could have sorted out the Zulu trouble in 1876. Why, for instance, is it then that the Transvaal and Natal governments of the time did not feel capable of dealing with the matter themselves? Is it generally known that the Zulus of that time had cavalry and firearms in large numbers and could use them efficiently?
Another item that also strikes one as not entirely correct is the statement that the Church of the Vow, Pietermaritzburg, was the first church north of the Orange River. It may have been the first Dutch Reformed church, but it was certainly not the first Christian church. In just about one of their first encounters across the Orange River the Voortrekkers came across an English missionary, his family and his church. The first in a series of English folk encountered by the Voortrekkers in just about every place they arrived at. This is also a history worth recounting.

The fact that the Voortrekkers left the Cape, often leaves the wrong impression that they were leaving a safe and civilized area and trekking into danger. This, also, is only partiy correct. Is it generally known that the English folk were at that stage already fighting a war on the Eastern Borders of the Cape on the basis of single families, each on their own farm, against large well-trained and organized Xhosa fighting units? How many South Africans today realize that the Xhosa of those days was a far fiercer and more formidable warrior than the Zulu, and that the numbers involved, people killed and duration of the wars against the Whites far exceeded most actions involving the Zulus?

These are only some of the aspects that need re-telling in a periodical like Militaria in a different way from that presented in school history books, so that each of our two major white population groups can take its own rightful place of honour in the history of our country.

Capt G.H.T. Johnson (SAN)

\section{EDITORS:}

There are not many articles on the history of the English speaking folk in South Africa in Militaria, but then again it is not the intention to publish articles on either the English or the Afrikaans speaking folk in this magazine. Militaria was originally intended to be a journal in which articles based on documents housed in the SADF Archives, which are closed to the general public, can be published. From the beginning of this year the nature of the magazine was changed to make space for articles of a general military nature. Any article which satisfies the basic conditions of objectivity, academic standard, and which is of a military nature, will be published (space permitting). 